Materiales de Construcción

Vol. 66, Issue 324, October-December 2016, e101

ISSN-L: 0465-2746

http://dx.doi.org/10.3989/mc.2016.06515

\title{
Concrete manufactured with crushed asphalt as partial replacement of natural aggregates
}

\author{
L. Coppola ${ }^{a}$, P. Kara ${ }^{b} \bowtie$, S. Lorenzi ${ }^{a}$ \\ a. University of Bergamo, (Dalmine (BG), Italy) \\ b. Riga Technical University (Riga, Latvia) \\ $\triangle$ patricija.kara@rtu.lv
}

\author{
Received 5 August 2015 \\ Accepted 14 April 2016 \\ Available on line 22 September 2016
}

\begin{abstract}
The paper focuses on the reuse of crushed asphalt (GA) as a partial replacement (up to 20\%) of natural aggregates for concrete manufacture. Addition of GA aggregates produced a positive effect on workability loss. The GA mixes, however, showed a significant tendency to bleed and segregate at the highest replacement percentage applied. GA led to a decrease of compressive strength in concrete (with respect to that of the reference concrete) up to $50 \%$ due to the weakness of the cement paste / recycled aggregate interface. To compensate for this negative effect, a reduction of w/c for the GA concretes was necessary. A decrease of w/c allowed the GA concretes to show drying shrinkage values substantially similar to those of reference concrete with the same cement factor. The experimental results confirmed the possibility of partial substitution ( $\max .15 \%$ ) of natural aggregates with crushed asphalt for making concrete.
\end{abstract}

KEYWORDS: Concrete; Waste treatment; Aggregate; Workability; Compressive strength

Citation/Citar como: Coppola, L.; Kara, P.; Lorenzi, S. (2016) Concrete manufactured with crushed asphalt as partial replacement of natural aggregates. Mater. Construcc. 66 [324], e101. http://dx.doi.org/10.3989/mc.2016.06515

RESUMEN: Hormigón fabricado con asfalto triturado como reemplazo parcial de áridos naturales. El artículo se centra en la reutilización del asfalto triturado (AM) como reemplazo parcial (hasta $20 \%$ ) de áridos naturales para la fabricación de hormigón. Los áridos de AM además produjeron un efecto positivo sobre la pérdida de la trabajabilidad. Las mezclas de AM mostraron una marcada tendencia a la exudación y segregación en el más elevado porcentaje de sustitución. El AM condujo a una disminución de la resistencia a la compresión en el hormigón (con respecto al hormigón de referencia) de hasta un 50\% debido a la debilidad de la pasta de cemento. Para compensar este efecto, fue necesaria una reducción de agua-cemento (a/c) para hormigones AM. Se consiguieron valores de retracción de secado sustancialmente similares a los de hormigón de referencia con el mismo contenido de cemento. Los resultados experimentales confirmaron la posibilidad de sustitución parcial (máximo 15\%) de áridos naturales por asfalto triturado para la fabricación de hormigón.

PALABRAS CLAVE: Hormigón; Tratamiento de residuos; Árido; Trabajabilidad; Resistencia a la compresión

Copyright: (C) 2016 CSIC. This is an open-access article distributed under the terms of the Creative Commons Attribution License (CC BY) Spain 3.0.

\section{INTRODUCTION}

In the last 15 years, sustainability has become an important research topic in the field of construction and building materials. The quantity of waste produced each year in the European Economic Area (EEA) is estimated at 3.0 billion tons, of which
$40 \%$ arises as construction and demolition waste (C\&DW) (1). The building industry, in fact, represents a significant nature-consuming activity (2), with the quarrying activities for the production of aggregates for concrete being expensive in terms of "environmental costs". In this view, in the last decade, much research (3-11) has been oriented to 
TABLE 1. Chemical composition of cement, $\%$ by mass

\begin{tabular}{lccccccccc}
\hline $\mathbf{S i O}_{2}$ & $\mathbf{A l}_{2} \mathbf{O}_{3}$ & $\mathbf{F e}_{2} \mathbf{O}_{3}$ & $\mathrm{TiO}_{2}$ & $\mathbf{C a O}$ & $\mathbf{M g O}$ & $\mathbf{S O}_{3}$ & $\mathbf{N a}_{2} \mathbf{O}$ & $\mathbf{K}_{2} \mathbf{O}$ & $\mathbf{C l}$ \\
\hline 16.25 & 3.86 & 1.59 & 0.2 & 60.34 & 2.34 & 2.58 & 0.15 & 0.67 & 0.054 \\
\hline
\end{tabular}

the partial substitution of natural aggregates by industrial by-products, in particular foundry sand and slag, rubber, glass, electric arc furnace slag and many other secondary materials.

Crushed asphalt (GA) is a typical by-product in the field of asphalt road rehabilitation. Reuse of this material is described in the EN 13108 standard, including material classification and testing. Generally, crushed asphalt is considered re-usable in the field of road construction. Indeed, a common practice of utilisation is based on re-heating the recycled aggregate to recover bitumen and mixing it with a specified amount of new bitumen to obtain a material with adequate physical properties for road applications. However, the asphalt recovery industry in some countries faces the problem of excessive material storage due to the limited quantities of GA that can be reused in new mixes. The storage costs in Italy are also high due to the classification of GA as waste rather than by-product. Hot reuse is, in fact, limited to $30 \%$ maximum substitution level in the case of new roads, and lower (less than 10\% in the top layer) in the case of road rehabilitation. The annual report of the European Association of Asphalt Manufacturers (12) estimates that there was an 11 million ton production of reclaimed asphalt in Italy in 2011 and only 20\% was recycled.

Cold reuse is suitable for bituminous sub-base and base layers where GA replaces natural raw materials. Cold recycling is an economical and environmentally friendly operation. No heating of GA is necessary, which means energy savings and reduced emissions. However, this technique is not very widespread compared to hot-recycling, yet it remains a good solution for temporary restoration such as road patches.

In this paper an alternative cold-recycling method is presented for using crushed asphalt in Portland cement concrete production. Feasibility of partial substitution of natural aggregates with crushed asphalt was evaluated in terms of rheological and physical properties of such concrete. This process was considered to help increase the percentage of recycling and solve the problem of excessive material immobilization in waste disposal before reuse in road construction.

\section{RESEARCH SIGNIFICANCE}

The reuse or recycling of by-products for concrete manufacture is a key-factor for sustainable development in the building industry. This research is devoted to the reuse of crushed asphalt for concrete manufacture - both to reduce the use of natural
TABLE 2. Density and water absorption of natural and waste aggregates

\begin{tabular}{lcc}
\hline Aggregate & Density $\left(\mathbf{k g} / \mathbf{m}^{\mathbf{3}}\right)$ & Water absorption (\%) \\
\hline CG & 2620 & 1.0 \\
CS & 2660 & 0.9 \\
FS & 2690 & 1.9 \\
GA & 2430 & 2.5 \\
\hline
\end{tabular}

aggregates and to dispose of GA waste. Crushed asphalt in Italy is mainly used for new road construction, especially in the sub-base and base layer. However, in the case of road maintenance and restoration, only a small fraction of crushed asphalt can be reused and the demand for waste storage dramatically increases. This research proposes an alternative cold recycling process for GA.

\section{MATERIALS AND METHODS}

Concrete mixes (GAC) were manufactured with GA as partial replacement for natural aggregates at levels of $5 \%, 10 \%$ and $20 \%$. Three series of concretes were manufactured; three samples were cast for each test. Rheological and mechanical behaviour were compared to those of the reference concrete (RC) manufactured only with natural aggregates.

\subsection{Materials}

Cement CE II/B-LL 32.5R (Italcementi limestone Portland cement) according to EN 197-1 was used. The chemical composition of this cement is reported in Table 1.

A superplasticizer (SP, ester of acrylic or methacrylic acid monomer) having $1000 \mathrm{~g} / \mathrm{mol}$ side chain length and an acid/ester ratio equal to 3.5 was used. Crushed asphalt was supplied by a local recycling company; it was not cleaned before turning it to aggregate, only air dried. The experiments aimed to reuse crushed asphalt on site, so no pre-soaking or conditioning was carried out to simulate real in-situ manufacturing. Three natural aggregates and GA were used (Table 2):

- CG: coarse gravel $(1 \div 30 \mathrm{~mm})$

- FS: fine sand $(0 \div 5 \mathrm{~mm})$

- CS: coarse sand $(8 \div 12 \mathrm{~mm})$

- GA: crushed asphalt $(10 \div 20 \mathrm{~mm})$

The grading of natural and GA aggregates was evaluated by sieve analysis according to EN 933-1 
(Figure 1). The grading of GA was similar to that of CG. However, the presence of a higher amount of fines was noticed (see Figure 1). Coarse sand, on the other hand, was significantly finer than GA. Chemical analysis of GA was also carried out according to EN 1744-1 noting that sulfate, sulfur, and soluble chloride contents were lower than the limits allowed by EN 12620. Petrographic analysis (EN 932-3) showed no gypsum, amorphous silica or pyrite in the GA. The methylene blue test (EN 9339) indicated no mud or clay being present in the GA.

Water absorption and density of natural aggregates and GA were evaluated according to EN 1097-6 (Table 2). GA showed higher water absorption, but lower density than natural aggregates as a consequence of its bituminous binder content.

\subsection{Mix design}

The concrete mixes were optimized (13-14) in order to evaluate the feasibility of replacing natural aggregates by GA. Both natural and GA aggregates were combined to meet the Bolomey curve, modified to take into account the cement factor of the mix. Concretes were made by increasing the amount of GA aggregates to replace natural aggregates up

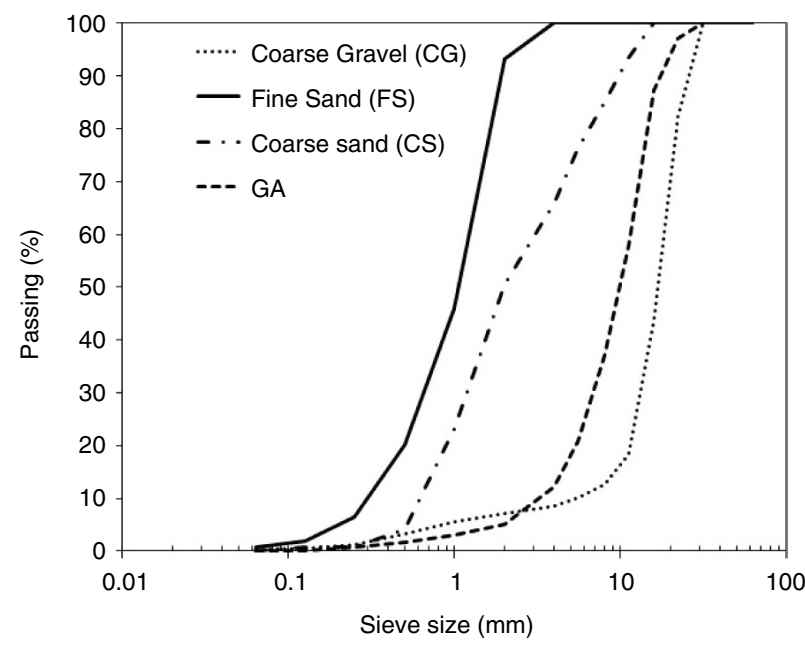

FIGURE 1. Grading of natural and GA aggregates. to $20 \%$ (by mass). Dry GA was used in the concrete and the water content was adjusted in order to compensate for the absorption of aggregates during the concrete mixing procedure (Table 2).

All concrete mixes were prepared in a powerdriven rotary mixer with a moving base (but without blades or paddles). The mixing procedure was as follows: first the dry components were mixed for 2 minutes, then $70 \%$ of the total water was added and mixed for 1 minute, then the rest of the water was added and mixed for one more minute. Superplasticizer was added to meet the target workability.

Three series of concrete mixes were prepared: the first (a) with a cement content of $330 \mathrm{~kg} / \mathrm{m}^{3}$ and a fixed w/c ratio of 0.53 (Table 3 ) for both the reference concrete and GA mixes. In the second series (b), the w/c ratio of the GA mixes was reduced to 0.45 whilst increasing the superplasticizer dosage and maintaining the same cement content as in the first series (mixes GA_b5\%, GA_b10\%, GA_b15\%, GA_b20\%) (Table 4). The third series (c) was made by increasing the cement content to $350 \mathrm{~kg} / \mathrm{m}^{3}$ and adopting a w/c ratio equal to 0.45 (mixes GA_c 5\%, GA_c 10\%, GA_c 20\%) (Table 5).

Samples were cast in $150 \mathrm{~mm}$ cube steel moulds, which conformed to EN 12390-1. The moulds were cleaned and lightly coated with oil before the casting procedure. Concrete was compacted on a vibrating table. After that, the samples were covered with polyethylene film and left to set for 48 hours. Then they were removed from the moulds and cured in water (at a temperature of $20 \pm 2^{\circ} \mathrm{C}$ )

TABLE 3. Concrete mixes for series (a)

\begin{tabular}{lccccc}
\hline Component & unit & RC & GA 5\% & GA 10\% & GA 20\% \\
\hline Cement & $\mathrm{kg} / \mathrm{m}^{3}$ & 330 & 330 & 330 & 330 \\
Water & $\mathrm{kg} / \mathrm{m}^{3}$ & 175 & 175 & 175 & 175 \\
w/c & & 0.53 & 0.53 & 0.53 & 0.53 \\
CG & $\mathrm{kg} / \mathrm{m}^{3}$ & 811 & 811 & 811 & 682 \\
CS & $\mathrm{kg} / \mathrm{m}^{3}$ & 869 & 775 & 681 & 625 \\
FS & $\mathrm{kg} / \mathrm{m}^{3}$ & 185 & 185 & 185 & 185 \\
GA & $\mathrm{kg} / \mathrm{m}^{3}$ & 0 & 85 & 171 & 342 \\
\hline
\end{tabular}

TABLE 4. Concrete mixes for series (b)

\begin{tabular}{lcccccc}
\hline Component & unit & RC & GA 5\% & GA 10\% & GA 15\% & GA 20\% \\
\hline Cement & $\mathrm{kg} / \mathrm{m}^{3}$ & 330 & 330 & 330 & 330 & 330 \\
Water & $\mathrm{kg} / \mathrm{m}^{3}$ & 175 & 149 & 149 & 149 & 149 \\
w/c & & 0.53 & 0.45 & 0.45 & 0.45 & 0.45 \\
CG & $\mathrm{kg} / \mathrm{m}^{3}$ & 811 & 811 & 811 & 811 & 682 \\
CS & $\mathrm{kg} / \mathrm{m}^{3}$ & 869 & 775 & 681 & 587 & 625 \\
FS & $\mathrm{kg} / \mathrm{m}^{3}$ & 185 & 185 & 185 & 185 & 185 \\
GA & $\mathrm{kg} / \mathrm{m}^{3}$ & 0 & 85 & 171 & 256 & 342 \\
\hline
\end{tabular}




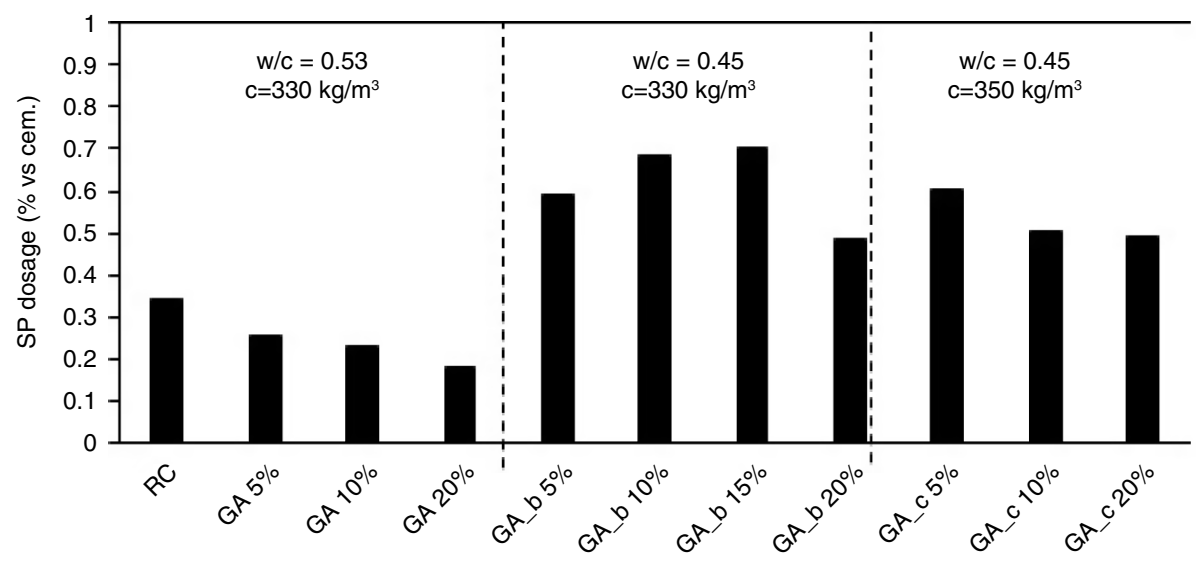

FIgURE 2. SP dosage for all concrete mixtures.

TABle 5. Concrete mixes for series (c)

\begin{tabular}{lccccc}
\hline Component & unit & RC & GA 5\% & GA 10\% & GA 20\% \\
\hline Cement & $\mathrm{kg} / \mathrm{m}^{3}$ & 330 & 350 & 350 & 350 \\
Water & $\mathrm{kg} / \mathrm{m}^{3}$ & 175 & 180 & 180 & 180 \\
w/c & & 0.53 & 0.45 & 0.45 & 0.45 \\
CG & $\mathrm{kg} / \mathrm{m}^{3}$ & 811 & 792 & 792 & 666 \\
CS & $\mathrm{kg} / \mathrm{m}^{3}$ & 869 & 756 & 665 & 610 \\
FS & $\mathrm{kg} / \mathrm{m}^{3}$ & 185 & 180 & 180 & 180 \\
GA & $\mathrm{kg} / \mathrm{m}^{3}$ & 0 & 83 & 167 & 334 \\
\hline
\end{tabular}

for 7 days and in a curing chamber (at an air temperature of $20 \pm 2{ }^{\circ} \mathrm{C}$ and relative humidity $\geq 95 \%$ ) for another 21 days or until testing, thus conforming to EN 12390-2.

Dosage of the polycarboxylate-based superplasticizer was adjusted for all mixes to attain the same $200 \mathrm{~mm}$ slump at the end of mixing (S4 class, according to EN 206-1) as the reference concrete. Slump was measured immediately at the end of mixing and 30 and 60 minutes thereafter according to EN 12350-2. Entrapped air and density were also evaluated on the fresh concrete according to EN 12350-6 and EN 12350-7, respectively. The density and compressive strength of the hardened concrete at 1, 7, 14 and 28 days were measured in accordance with EN 12390-2. Finally, elastic modulus at 28 days and drying shrinkage up to 120 days were determined on the hardened concrete according to EN 12390-13 and UNI 11307 respectively.

\section{EXPERIMENTAL RESULTS AND DISCUSSION}

\subsection{Tests on fresh concrete}

The addition of increasing percentages of GA in the concrete mixes reduced the superplasticizer demand as evidenced in Figure 2 (first

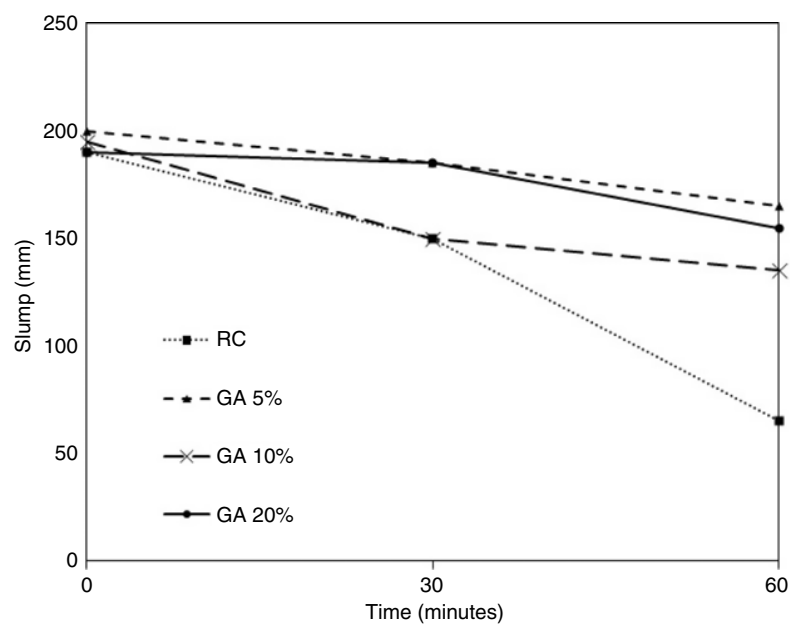

FIGURE 3. Slump loss of GA and reference concretes with $\mathrm{w} / \mathrm{c}=0.53$ and $330 \mathrm{~kg} / \mathrm{m}^{3}$ cement content.

series concretes). The superplasticizer dosage was in the range of $0.2-0.4 \%$ for the mixes at $0.53 \mathrm{w} / \mathrm{c}$ ratio and $330 \mathrm{~kg} / \mathrm{m}^{3}$ cement dosage. In the second and third series, the superplasticizer dosage was increased (vs that of the first series) as a consequence of the lower w/c ratio ( 0.45 vs 0.53$)$ (see Figure 2).

Higher GA addition led to higher workability at 60 minutes (Figure 3). Despite the higher water absorption of GA with respect to natural aggregates, the GA addition produced positive effects on workability retention. This could probably be attributed to the rounded shape of natural aggregates and also to the presence of oil traces that act similarly to superplasticizer for granting higher initial fluidity and prolonged workability. This effect can be considered beneficial for prolonged transportation or placing of concrete, especially in hot climates. Flow table tests were carried out according to EN 12350-5 and confirmed the slump test results (Figure 4). The same tendency was also evidenced in the case of concrete mixes 


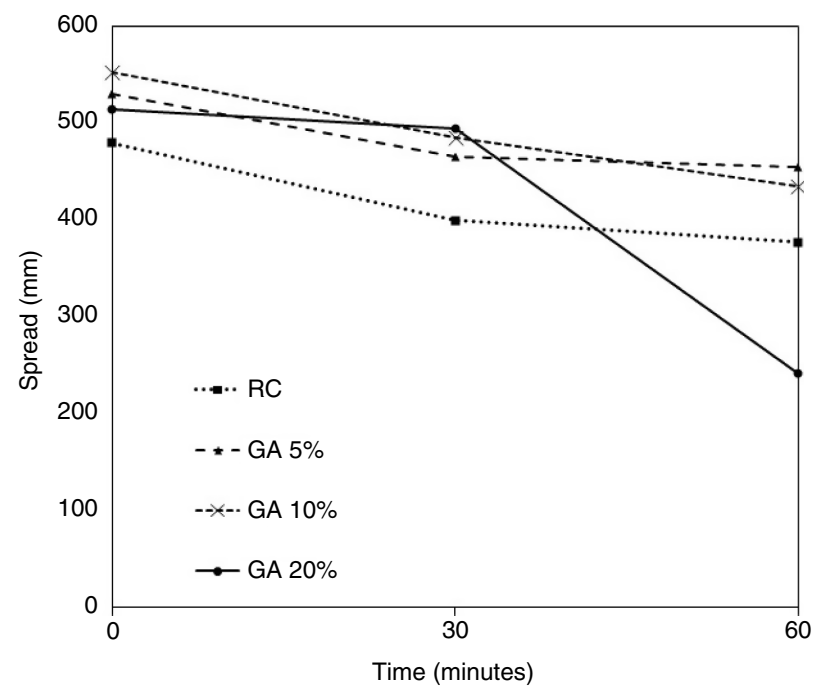

Figure 4. Flow value of GA and reference concretes as a function of time with $\mathrm{w} / \mathrm{c}=0.53$ and $330 \mathrm{~kg} / \mathrm{m}^{3}$ cement content.

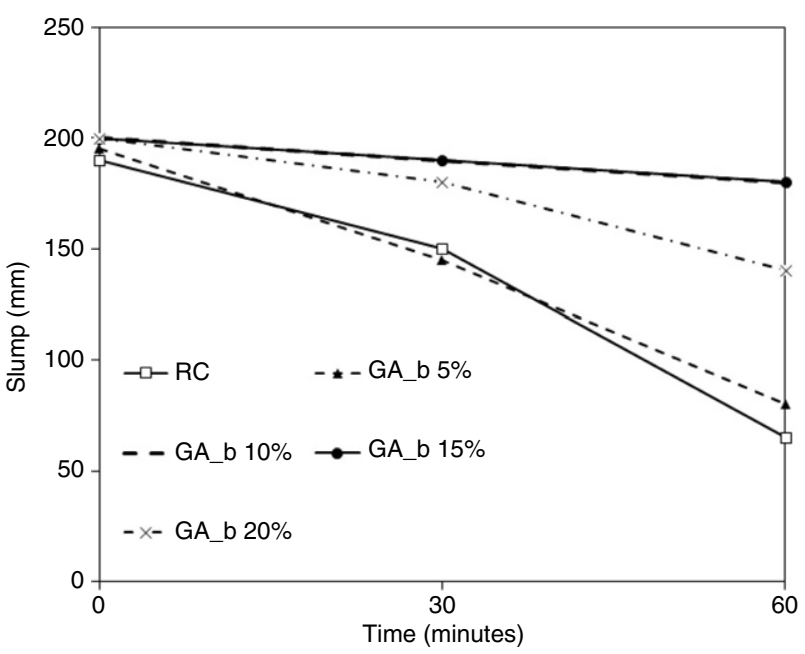

FIgURE 5. Slump loss of GA concretes $(\mathrm{w} / \mathrm{c}=0.45)$ and reference concrete $(\mathrm{w} / \mathrm{c}=0.53)$ at $330 \mathrm{~kg} / \mathrm{m}^{3}$ cement content

with a w/c ratio equal to 0.45 (second and third series). The addition of GA beyond 5\% produced a drastic reduction in the 60 minute workability loss of concrete (Figure 5). In concretes with a cement content of $350 \mathrm{~kg} / \mathrm{m}^{3}$, GA addition was responsible for a very low workability loss, independently of the replacement percentage of GA (Figure 6).

No bleeding or segregation tendency was detected for any of the concretes except for the mix with $20 \%$ of GA. For this reason, the maximum percentage of GA to avoid bleeding must be limited to $15 \%$. No anomalous air entrapment was noticed for any of the mixes. The density of GA concretes was substantially similar to that of $\mathrm{RC}$ with only natural aggregates.

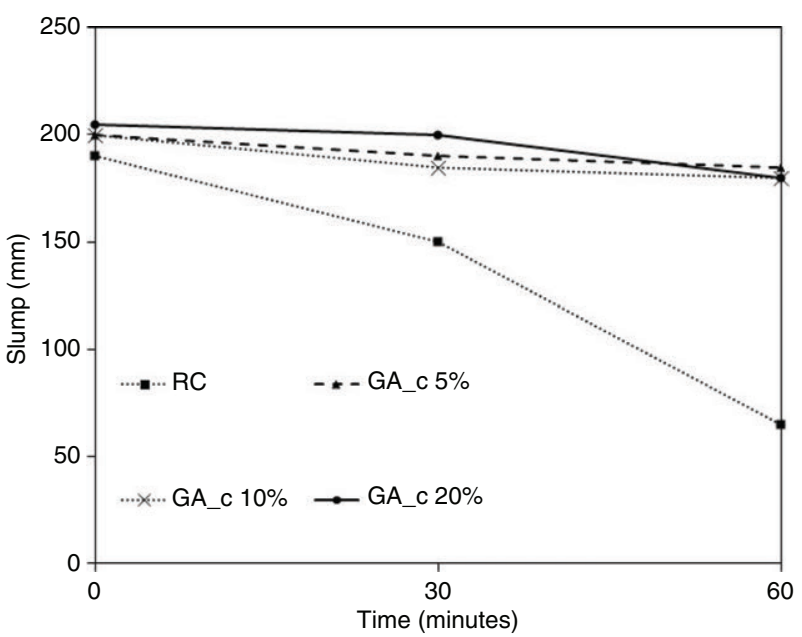

Figure 6. Slump loss of GA concretes (w/c $=0.45$ and 350 $\mathrm{kg} / \mathrm{m}^{3}$ cement content) and reference concrete (w/c $=0.53$ and $330 \mathrm{~kg} / \mathrm{m}^{3}$ cement content).

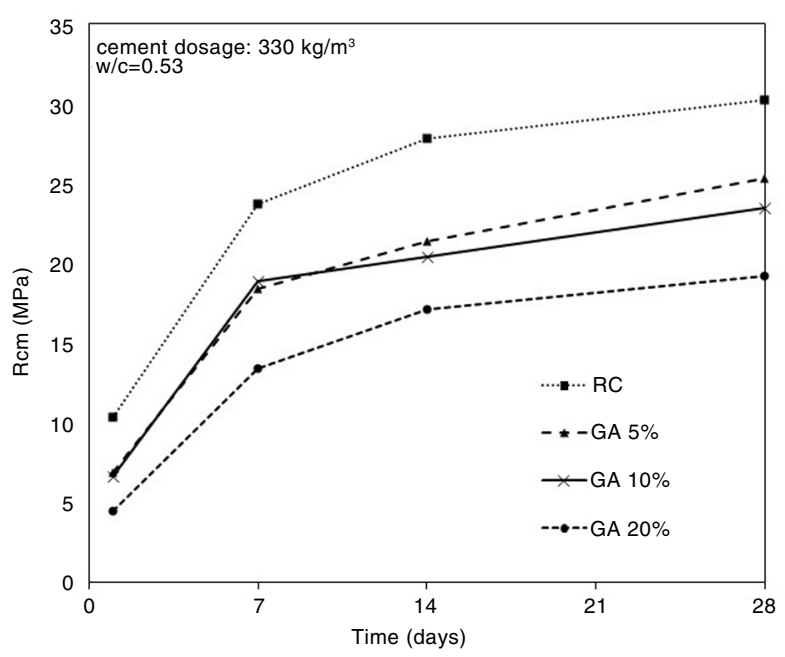

FIgURE 7. Compressive strength vs. age of GA and reference concretes with w/c $=0.53$ and $330 \mathrm{~kg} / \mathrm{m}^{3}$ cement content.

\subsection{Tests on hardened concrete}

Compressive strength tests were carried out to evaluate the effect of GA addition on the mechanical properties of concrete. An increase in GA addition produced a decrease in compressive strength of concrete at early ages (Figure 7).

The compressive strength decrease is evident for the highest substitution of natural aggregates; at $20 \%$ substitution, the compressive strength decrease of GA concrete was about $50 \%$ with respect to RC. This could probably be ascribed both to the presence of oils in bitumen that adversely affect the kinetics of cement hydration and to a poor aggregate-cement paste interface, as evidenced by the failure paths during the compressive strength tests. The preferential 
crack propagation detected by visual observation, in fact, was through the cement paste-GA interfaces, in the zones where the presence of hardened bitumen was high. However, the reduction of the w/c ratio (second series: $b$ ), produced a positive effect on the compressive strength of concrete prepared with GA aggregates (Figure 8), as expected. Compressive strength values are similar for RC and GA concretes up to $15 \%$ substitution level; yet any further increase up to $20 \%$ produces a $15-20 \%$ reduction in strength. As expected, the same effect was evidenced also at the highest cement dosage (Figure 9). In conclusion, on the basis of the compressive strength test results, GA use should be limited to $15 \%$ replacement.

Drying shrinkage was also measured on samples made with a cement content of $330 \mathrm{~kg} / \mathrm{m}^{3}$,

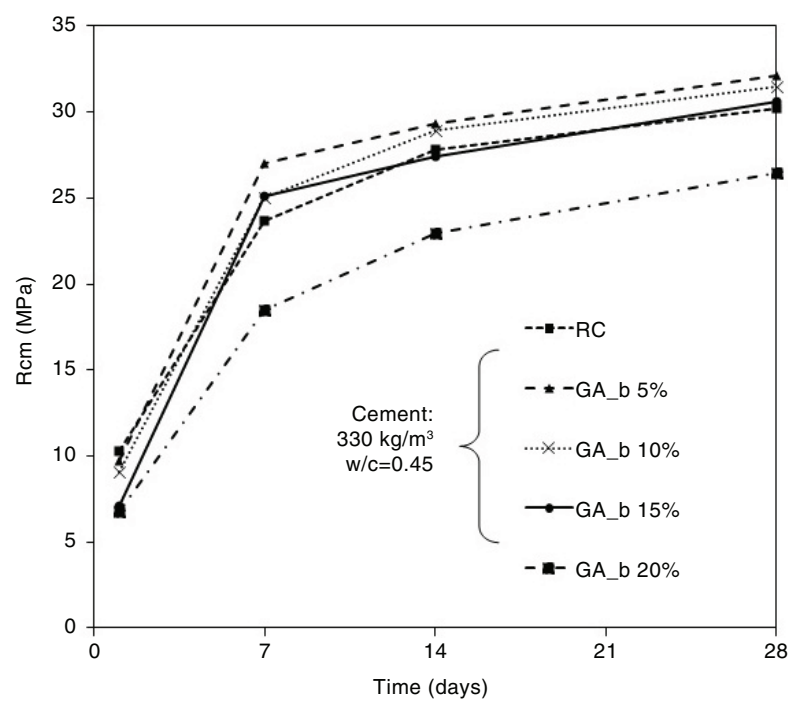

Figure 8. Compressive strength vs. age of GA concretes (w/c $=0.45$ and $330 \mathrm{~kg} / \mathrm{m}^{3}$ cement content) and reference mixture $\left(\mathrm{w} / \mathrm{c}=0.53\right.$ and $330 \mathrm{~kg} / \mathrm{m}^{3}$ cement content).

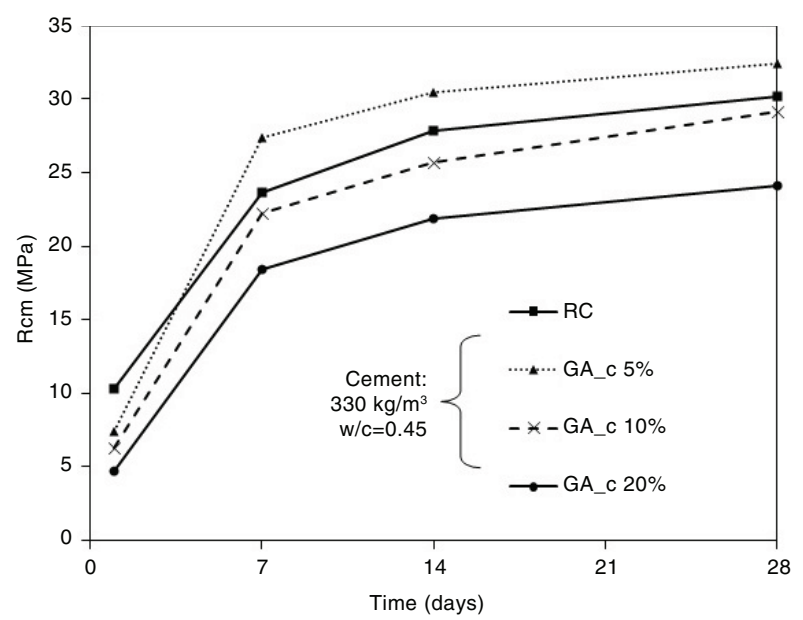

Figure 9. Compressive strength vs. age of GA concretes $\left(\mathrm{w} / \mathrm{c}=0.45\right.$ and $350 \mathrm{~kg} / \mathrm{m}^{3}$ cement content) and reference mixture $\left(\mathrm{w} / \mathrm{c}=0.53\right.$ and $330 \mathrm{~kg} / \mathrm{m}^{3}$ cement content $)$. $\mathrm{w} / \mathrm{c}=0.45$ and $5-15 \% \mathrm{GA}$ replacing natural aggregates (Figure 10). Data were compared to those collected for RC with $330 \mathrm{~kg} / \mathrm{m}^{3}$ cement content and $w / c$ ratio equal to 0.53 . Drying shrinkage of GA mixes was similar to that of the reference mix. However, it must be noted that GAC was prepared at a lower w/c ratio with respect to $\mathrm{RC}$ (at the same cement content). Consequently, the volume of cement paste, responsible for shrinkage, was lower for GAC vs RC. Hence, it can be concluded that the GA addition had a negative effect on shrinkage. This can probably be attributed to the lower stiffness of GA with respect to natural aggregates.

Young's modulus of hardened concrete was measured on cylindrical samples at 28 days (UNI-EN 6556). The higher the GA replacement the lower the Young's modulus, see Figure 11. However, reduction in w/c ratio ( 0.45 vs 0.53 ) allowed achievement of a Young's modulus for the $15 \%$ substitution of natural aggregates similar to that of RC.

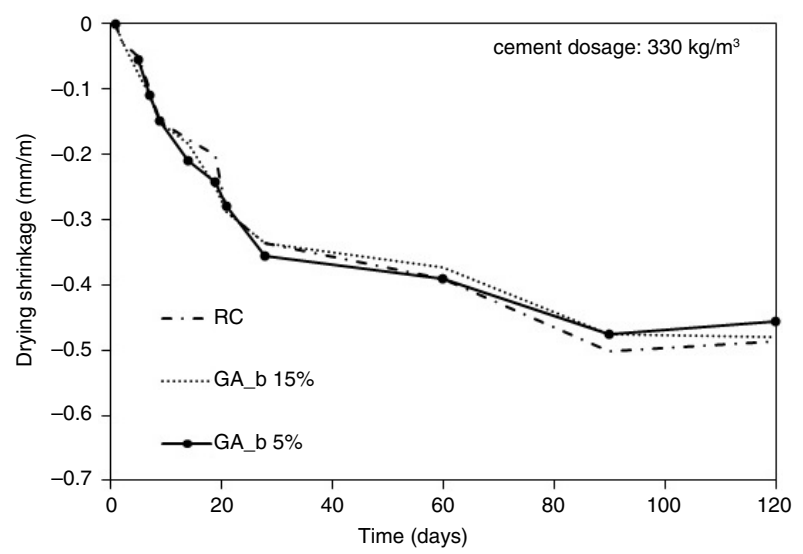

FIGURE 10. Drying shrinkage of GA concretes $(\mathrm{w} / \mathrm{c}=0.45$ and $330 \mathrm{~kg} / \mathrm{m}^{3}$ cement content) and reference mixture ( $\mathrm{w} / \mathrm{c}=0.53$ and $330 \mathrm{~kg} / \mathrm{m}^{3}$ cement content).

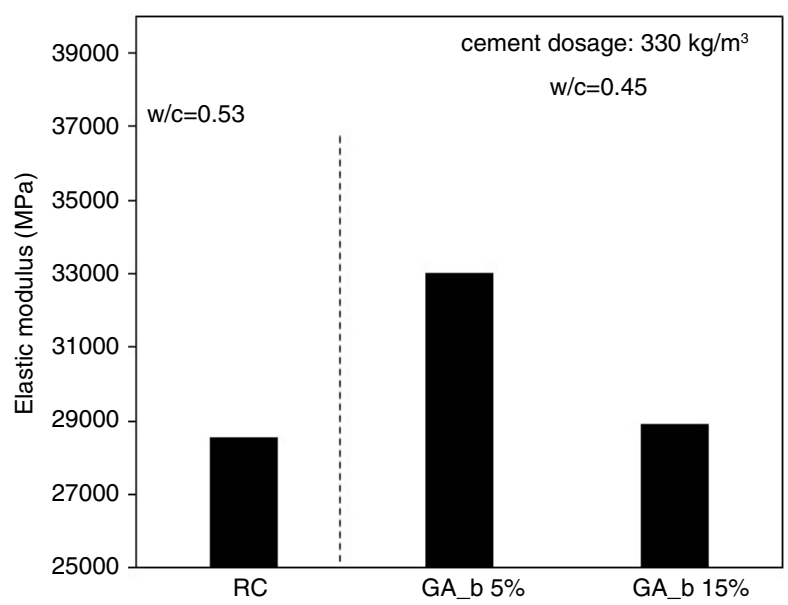

FIGURE 11. Young's modulus of GA concretes $(\mathrm{w} / \mathrm{c}=0.45$ and $330 \mathrm{~kg} / \mathrm{m}^{3}$ cement content) and reference mixture ( $\mathrm{w} / \mathrm{c}=0.53$ and $330 \mathrm{~kg} / \mathrm{m}^{3}$ cement content). 


\section{CONCLUSIONS}

Results of an experimental study are presented to evaluate the substitution of natural aggregates by crushed asphalt in concrete. This addition produced positive effects on both initial workability and workability retention. The effect could probably be ascribed to the presence of oil traces that can play a synergistic role with the superplasticizer. However, the substitution percentage of crushed asphalt must be limited to $15 \%$ in order to avoid bleeding and segregation. The higher the crushed asphalt substitution is the lower the compressive strength. A $50 \%$ strength decrease was noticed when GA was used at 20\% replacement, which can be ascribed both to the weakness of the cement paste / recycled aggregate interface and to the presence of oils in bitumen that adversely affect the kinetics of cement hydration, although reduction of w/c ratio mitigated this effect. The maximum substitution rate of GA is best limited to $15 \%$ to avoid both rheological and mechanical underperformance. Reusing GA in concrete also led to increased drying shrinkage. However, the improvement of cement paste quality, i.e. the reduction of w/c ratio, should limit this effect. The higher the GA replacement is the lower the Young's modulus. However, reduction in w/c ratio ( 0.45 vs 0.53$)$ allowed achieving a similar Young's modulus for the $15 \%$ substitution of natural aggregates than for RC. In all, the experimental work evidences the feasibility of partial substitution of natural aggregates by crushed asphalt in concrete.

\section{REFERENCES}

1. Silva, R.V.; Brito, J.; Dhir, R.K. (2014) Properties and composition of recycled aggregates from construction and demolition wastes suitable for concrete production. Constr Build Mater, 65, 201-217. http://dx.doi.org/10.1016/j. conbuildmat.2014.04.117

2. Coppola, L.; Cerulli, T.; Salvioni, D. (2005) Sustainable Development and Durability of Self-Compacting Concretes.
Proceedings of 11th International Conference on Fracture 2005. ICF11, 3, 2226-2241.

3. Ramachandran, V.S. (1981) Waste and By-products as Concrete Aggregates. Canadian Building Digest. CBD-215, National Research Council, Ottawa, Canada. http://www. irc.nrc-cnrc.gc.ca

4. Blengini, G.A.; Garbarino, E.; Šolar, S.; Shields, D.J.; Hámor, T.; Vinai, R.; Agioutantis, Z. (2012) Life Cycle Assessment guidelines for the sustainable production and recycling of aggregates: the Sustainable Aggregates Resource Management project (SARMa). J Clean Prod, 27, 177-181. http://dx.doi.org/10.1016/j.jclepro.2012.01.020

5. Coppola, L.; Lorenzi, S.; Marcassoli, P.; Marchese, G. (2007) Concrete Production by Using Cast Iron Industry By-Products. Industria Italiana del Cemento. 836, 748-756.

6. Coppola, L.; Lorenzi, S; Buoso, A (2010) Electric arc furnace granulated slag as a partial replacement of natural aggregates for concrete production. Second International Conference on Sustainable Construction Materials and Technologies. Ancona, Italy. http://www.claisse.info/ Proceedings.htm

7. Gimenez, M.; Bouillon, C.; Ferey, F.; Sorrentino, F. (2005) Zero Waste. World Cement 09.

8. Kara, P. (2013) The next generation ecological self compacting concrete with glass waste powder as a cement component in concrete and recycled concrete aggregates, Proceedings of $3^{\text {rd }}$ Workshop on The new boundaries of structural concrete, University of Bergamo - ACI Italy Chapter, Bergamo, Italy, October 3-4, 2013, 21-30.

9. Courard, L.; Frédéric, M.; Delhez, P. (2010) Use of concrete road recycled aggregates for roller compacted concrete, Constr Build Mater, 24, 390-395. http://dx.doi. org/10.1016/j.conbuildmat 2009.08.040

10. Pasandin, A.R.; Perez, I. (2015) Overview of bituminous mixtures made with recycled concrete Aggregates. Constr Build Mater, 74, 151-161. http://dx.doi.org/10.1016/j. conbuildmat.2014.10.035

11. Modarres, A.; Hosseini, Z. (2014) Mechanical properties of roller compacted concrete containing rice husk ash with original and recycled asphalt pavement material. Mater Design, 64, 227-236. http://dx.doi.org/10.1016/j. matdes.2014.07.072

12. EAPA (2011) Asphalt in Figures 2011. European Asphalt Pavement Association.

13. Coppola, L. (2001) Rheology and Mix Proportioning of Self-Compacting Concretes. Industria Italiana del Cemento. 762, 152-163.

14. Zhang, Y.; Collepardi, M.; Coppola, L.; Guan, W.L.; Zaffaroni, P. (2003) Optimization of the High-Strength Superplasticized Concrete of the Three-Gorge Dam in China. Industria Italiana del Cemento, 783, 58-69. 